\title{
CORPORATE DIVERSIFICATION AND FINANCIAL PERFORMANCE OF CONGLOMERATE FIRMS IN NIGERIA
}

\author{
Mayowa Gabriel AJAO ${ }^{1)}$, George Abayomi KOKUMO-OYAKHIRE ${ }^{2)}$ \\ ${ }^{1,2)}$ Department of Banking and Finance, Faculty of Management Sciences, University of Benin, Benin City, Nigeria \\ Corresponding author: ajao.mayowa@uniben.edu; oyakhire.george18@gmail.com
}

\begin{abstract}
This study examined the effect of corporate diversification on the financial performance of conglomerate firms in Nigeria. The nine (9) conglomerates firms listed on the Nigerian Stock Exchange as of 2019 formed the population and sample size for this study from 2011 to 2019. Corporate diversification was measured by; product, operational and geographical diversification. Panel least-square analytical method was used. Twopanel co-integration models were developed for empirical analysis to measure financial performance using Return of Assets (Book Value) and Tobin's Q (Market Value). The study's findings revealed that product diversification has a positive impact on the financial performance of conglomerates in Nigeria. However, operational and geographical diversification showed a negative but significant relationship between corporate diversification and the financial performance of conglomerates in Nigeria. It was concluded that corporate diversification has a dominant-negative impact on financial performance. However, only one form of corporate diversification (product) was positively related to financial performance. Therefore, the study recommends that conglomerates focus more on implementing geographical diversification strategy than other types of diversification as it encompasses a great deal of product and services promotions, which is key to improving annual sales and product awareness.
\end{abstract}

Keywords: Diversification, Conglomerates, Performance, Book Value, Tobin Q

\section{Introduction}

Diversification as a management strategy is commonly used for business activities related to expansion into an extensive range of growing operations, which may include the addition of new markets, services, products, or various stages of production into the already existing business. Diversification entails a strategic process a firm will extend its core business into additional product markets. According to Sumra and Muhammad (2014), diversification is a strategy used to reduce the business risk of an organization by adding markets, products, services, customers, and, most importantly, locations to the organization's portfolio.

Over the years' corporate diversification has become an essential strategy for many public limited companies. With these new strategy adjustments, firms have reacted rapidly and retained their competitive advantages (Nasiru, Ibrahim, Yahya \& Aliyu, 2011). In the early 1980s, most multinationals lost their competitiveness due to a lack of efficient performance, which made most researchers believe that focused firms had better chances of survival than diversified firms when creating shareholder value. Hans, John, and Jacqueline (2004) mentioned the dispute ask whether diverse organizations are efficient. Diversified firms with well-established interests and financial discipline tend to apportion organizational resources more efficiently and effectively than firms that are not diversified. Ugwuanyi and Ugwu (2012) argued that diversified firms tend to outperform non-diversified firms when their abilities are exploited and maintain financial discipline rather than natural resources to empire-building.

Corporate diversification is based on related or unrelated diversification considerations, and management decides the whole diversification process and strategy for either related or unrelated businesses. In situations where management is familiar with the new market and technology of the related business, diversification could give considerable outcomes as it can also reduce the firm's risk, as stated earlier. Unlike related diversification, unrelated diversification tends to offer a lesser incremental value and has a negative effect on the systematic risk of the firm (Athar, Irfan \& Majid, 2012). Academics and business professionals have over time debated on the advantages and disadvantages of diversification and its profound influence on a firm's financial success. Related diversification also increases shareholders value while unrelated diversification tends to decreases shareholders value (Archana \& Saumitra, 2015).

No much attention has been paid to the impact diversification have on companies' profitability in developing economies. This has created a limit to which the results and development of a global diversification hypothesis can be generalized to developing countries. The extent to which firms in developing countries use corporate diversification options and the degree to which such corporate diversification helps improve the firms' financial performance, and development has not been extensively studied (Oyedijo, 2012). Oyedijo (2012) states that several firms operating in different sectors in Nigeria have diversified their portfolios to spread their business risks, improve financial performance, and hedge against the challenges of a deregulated economy. Such diversification strategic moves are yet to be tested empirically. Diversification has various assumed benefits, such as the spreading of risks and synergy that will arise from the economics of scale (Ongeri, 2014). Firms operating in some developing nations (Nigeria 
inclusive) most times cannot prevent a failure in the diversification of the corporation product market. Thus, it is essential for an empirical investigation into the impact of corporate diversification strategy on the financial performance of firms.

For Nigerian firms to compete globally, it is essential that firms develop and implement suitable growth strategies that enhance sales growth and cut down costs. When not monitored effectively, product diversification can make managers aggressive and biased to pursue the interest of their product division at the expense of the entire conglomerate. Studying product diversification's effect on financial performance alone would reveal a positive relationship, but this does not show a fair view of its impact on financial performance because management can simply excel in selling a product line at the expense of other functional areas conglomerate.

The costs associated with geographical diversification may outweigh the benefits during the first few years of implementation. Therefore, most conglomerates tend to only measure the impact of geographical diversification on financial performance in the short run, without considering its long-term impact on its financial performance. Using geographical diversification alone to establish a relationship with financial performance may provide insignificant findings that would be misleading in the long run.

Conglomerate/Operational diversification strategy like geographical diversification tends to increase the operating cost of running an unrelated business. Management of conglomerates are involved in operating new portfolios and may not have adequate experience or skills, which tend to create dwelling financial performance. Most researchers carried out empirical studies, using either Market value (Talat, Choudhary \& Mian, 2008) or book value (Pandya \& Rao, 1998; Ugwuanyi \& Ugwu, 2012) as a measure of financial performance and use only one type of corporate diversification to test the financial performance of a firm empirically. However, there seems to be a knowledge gap when focusing on just one financial performance measure of organizations that diversified their portfolio. There is the need to investigate other forms of diversification (Product, Operational/Conglomerate, and Geographical) together to identify the one that has the most significant impact on organizational performance. The study focuses on corporate diversification and the financial performance of conglomerate firms listed on the Nigerian Stock Exchange for ten years (2010 to 2019). The choice of this period is based on the fact that it covers all the listed conglomerate firms on the Nigerian Stock Exchange.

\section{Literature Review \\ Corporate Diversification}

John and Lang (2003) thought that there had been no agreement as to the definition of diversification among researchers, where mixed expectations on theories have been provided given that corporate diversification enhances the value and, at the same time, destroy values Diversification for this purpose was identified by Kuria (2016) as a strategic activity utilized to sustain company competitiveness and at the same time generate value by serving as a platform for financial economies. One way managers create internal resource markets is by increasing the pool of resources from which they may draw upon. In contrast to the benefit Kuria (2016) outlined, Meysam, Melati, and Zuhaimy (2015) stated that a diversification strategy can destroy corporate value because capital allocation inefficiency among diversified divisions of firms may lead to a decline in firm performance and thus destroy firm value. Since businesses operate in several segments, it is more difficult to establish a pay package for managers that work for all of them (Talat, Choudhary \& Mian, 2008). Kotler and Armstrong (2008) defined diversification as a strategy where a firm acquires businesses/product lines external to its existing products and markets. Most managers diversify and, in most cases through acquisition, mainly to boost their reward/benefits, secure their jobs, or widen their scope of control in the firm. Diversification allows firms to pursue efficiency in product and market and reduce business risk through investing in a greater variety of services (Archana \& Saumitra, 2015). However, reducing risk is not a suitable reason for diversification. The owners of publicly-traded organizations/firms may choose to reduce their risk when they invest in a non-diversified portfolio. They can gain a reduced risk of diversification without incurring agency costs. In this case, diversification would seem beneficial if it provides economies of scale that will support the firm's growth and enhanced financial performance.

A diversification strategy is undertaken by a corporation when there is an opportunity implanted in the structures of the market choice of the firm willing to diversify (Oyedijo, 2012). This signifies that in diversifying into new businesses (related or unrelated), corporations tend to become part of a strategic action if they still possess underutilized resources after they consolidate their position in their core/current market. Diversification is assumed to raise the economic benefits the firm would derive through better efficiency of resources across various markets (Clarke, 1985).

\section{Empirical Review}

Pandya and Rao (1998) researched diversification and firm performance. Their interdisciplinary research was aimed to validate if firm-level diversification has a positive effect on the company's financial performance, which was assessed by ROA. The study finds that, on average, diversified firms showed better 
performance than firms that are not diversified. On the other hand, highly-diversified enterprises had lower returns and more minor inconsistencies. The results revealed that diversified firms outperformed undiversified enterprises in risk and return.

John and Lang (2003) verified that geographic diversification increases a firm's shareholders' value and develops its long-term financial performance if they decide to undertake a related geographical diversification strategy. Hans, John, and Jacqueline (2004) attempted to quantify international and product diversification's impact on the publishing industry by implementing the diversification strategy for largesized publishing organizations. The study concluded that large-sized publishing firms from the sampled firms might need to diversify into a various related business-like, information industry, communication services industry, and products industry.

To learn more about how global and industry diversity influences business value and operating performance, Steven, Trahan, and Gopala (2004) set out to explore this directly by using a database of Centre for Research in Security Prices yielded statistics on inventory return (CRSP) of 194 U.S.A firms that took over foreign firms between 1985 and 1998 using cross-sectional regression analysis. The study finds that there tends to be a significant cross-sectional correlation between the period of a firm announcing its intention to diversify or acquire another firm, Tobin's q firm to be accepted, and the method of acquisition.

According to a study by Murali, Chari, Sarv, and Parthiban (2007), firms that have diversified their operations internationally saw a rise in financial performance. The sample size of 131 IT firms between 1995 and 1996 was selected. Empirical tests revealed that investing in information technology may help a firm efficiently influence its definite assets in foreign markets, which may also contribute to its increased financial performance.

Nigel, Jun, and Sourafel (2008) analyzed the correlation between multinationality and firm financial performance in "Optimal Geographic Diversification and Firm Performance: Evidence from the U.K." The research was based on 400 multinational firms in the United Kingdom between 1990 and 1999, which comprised the service and manufacturing sectors. Results from the research verified a non-linear correlation between financial performance and multinationality. However, in trying to correct the endogeneity of an investment decision, multinationality in the studied firms tends to be greater than other firms and, as such a higher degree of international diversification.

Chia-Wen and Heng-Yih (2008) examined corporate diversification and firm performance using longitudinal data that contained operational information at the firm level between 1997 and 2002. The empirical results stated that a firm's product and customer diversification tend to be positively correlated with the firm's financial performance. But geographic diversification tends to be negatively associated with a firm's financial performance. A sample size of 124 consisting of hardware manufacturing firms in Taiwan was derived from the firms listed on the Taiwan Stock Exchange (TSE). The result suggested that the product diversity tends to be a critical determinant of the firm performance over time. Talat, Choudhary and Mian (2008), researched on the effects diversification has on corporate financial performance of firms in Pakistan. The KSE-100 index firms formed the population of the study while the sample size was made up of 65 firms. Return on Assets (ROA), Return on Equity (ROE), Market Rate of Return (MKTR), and Tobin's q were used to examine financial performance as an independent variable, while the coefficient of variation was used to assess risk. The results demonstrate that non-diversified companies tend to do better than diversified companies.

A study by Imen and Mehdi (2011) was carried out to determine if corporate diversification can provide an environment beneficial for management earnings (considering the agency conflicts hypothesis) or whether it mitigates this phenomenon (earnings volatility hypothesis). Results showed that there tends to be management earnings problems in diversified firm as compared to a constructed portfolio of undiversified firms chosen to estimate the segments of the multinational firm. The study also find that geographic diversification can lead to an increase in management earnings which is in agreement with the agency hypothesis, whereas an industrial diversification strategy can decrease management earnings, which is in agreement with earnings volatility hypothesis. The study concluded that the earnings of management is practiced more in a firm that is geographically diversified and also in firms that employ both industrial and geographical diversification. Nasiru, Ibrahim, Yahya and Aliyu (2011) evaluated the impact of product diversification on financial performance of selected Nigerian construction firms between 1997 and 2001, where the specialization ratio (SR) was used to categorize these firms into undiversified, moderately diversified and highly diversified. Performance of the construction firms was measured using various profitability ratios like the return on assets. The findings from the study revealed that highly diversified firms might not perform better than undiversified firms in terms of profitability ratios. This leads to a nonsignificant linear relationship between the extent a firm is diversified and the firm's financial performance.

In the study of the effects of product market diversification strategy on corporate financial performance and growth of selected firms in Nigeria, Oyedijo (2012) examined how Nigerian firms performed with regards to related and unrelated diversification strategies within five (5) years (2006 -2010). The empirical results using a panel regression of the Fixed Effect test showed that there tends to be a positive significant linear relationship between the financial performance of firms and their rate of growth concerning a related 
diversification strategy. Additionally, the panel regression analysis found that a related diversified strategy positively affected performance, but an unrelated diversification method had the opposite effect.

Athar, Irfan, and Majid (2012) studied the impact diversification has on a firm's financial performance in Pakistan. The sample size of 40 firms was limited to listed manufacturing firms on the stock exchange whose total revenues were segmented into product diversification for five years (2005-2009). The ANOVA test showed differences in the firm's financial performance concerning the classifications/categories. In terms of risk and return, the three categories - highly diversified, moderately diversified, and undiversifiedproduced equivalent results and hence had no relevance to organizations' financial performance.

Ugwuanyi and Ugwu (2012) studied the effect of corporate diversification on financial services firms' profitability in Nigeria between 1998 and 2007. The independent variable (corporate diversification) was estimated by Operational Diversification, Geographical Diversification, and the Log of Total Assets, the dependent variable (profitability) was calculated using Return on Total Assets. The empirical results showed that diversification tends to have a significant positive impact on banks' profitability because diversified banks can collate their internally generated funds and reallocate them to other profitable functional departments. This finding was corroborated by Pisedtasalasai and Edirisuriya's (2020) findings, which studied the impact of diversification on the performance of Sri Lankan banks.

Detailed analysis on the correlation between a firm's decision to diversify into the financial services industry and its impact on financial performance was carried out by Sumra and Muhammad (2014) from 1985 to 1996. Total Assets Turnover, Earnings before interest and tax Margin, and the firm's growth rate were used as independent variables to test for profitability, operational efficiency, and growth. The dependent variables for the study were Return on Equity (ROE) and Return on Assets (ROA). The study concluded that there was no positive impact of diversification on the financial performance of the firms under study. Also, diversifying into the financial services industry was more cost-effective while considering that the firm's risk may tend to increase.

To determine the impact Information and Communication Technology (ICT) has on the performance of Nigerian firms, Akewushola (2015) selected 12 firms that are diversified by their product market. The study measured related diversification by the extent to which diversification arose from several firms operating in the same industry. Findings from the study showed that a unit change in firms diversified by related productmarket in terms of adoption of ICT and investment would increase the level of financial performance of the firm.

Jasper (2016) investigated the impact diversification and the financial crisis had on India's firm performance from 2006 to 2012. Accounting-based measures of financial performance and market-based indicators of company performance were used in the study to assess firm performance. Results from the study show that diversified firms tend to have higher firm performance when compared to non-diversified firms. It was also noted that during a global economic meltdown, diversified and non-diversified firms in India had negative financial performance.

Kuria (2016) employed related products diversification, unrelated product diversification, and geographic diversification to evaluate business diversification on financial performance (Return on Assets) from 2011 to 2015 for firms listed on the NSE using multiple regression analysis. According to findings from the study, there is a direct link between product diversity and overall financial performance. Implementing a product diversity strategy among non-financial enterprises at the NSE would result in improved financial performance.

To examine the effects different factors have on the diversification strategy of firms, Salma and Hussain (2018) sampled a number of 465 firms from India, Sri Lanka and Pakistan to determine how a diversification decision affects manufacturing firms across south Asian countries from 2001 to 2016. A two-stage regression analysis was employed for this study, where the dependent variable was measured by director ownership, firm growth, firm risk, firm size, managerial ownership, and debt ratio. Empirical results established a significant positive relationship between corporate diversification and firm performance. This proves that corporate diversification significantly impacted firm performance across south Asian countries within the study's limits.

The impacts of corporate diversity on company performance in the Serbian insurance market were investigated by Ranka, Vladimir, and Dragan (2017). The study provided experimental verification on the correlation between Product diversification and financial performance of 23 insurance firms operating in Serbia between 2004 and 2014. The study's empirical results showed a significant positive relationship between corporate diversification and firm financial performance. This indicates that diversified insurance firms in Serbia tend to outperform undiversified insurance firms. Odunayo, Stephen, and Mabutho (2017) researched the effect an operational diversification strategy has on the financial performance of banks from 2006 to 2015 for 250 commercial banks in 30 Sub-Saharan nations using the random System Generalized Method of Moments (SYS-GMM). The study concluded that operational diversification in Sub-Saharan Africa commercial banks affects their financial performances as measured by ROA significantly.

The impact of corporate diversification and financial structure on financial performance was investigated by Mehmood, Hunjra, and Chani (2019) for 520 manufacturing companies from Pakistan, India, Sri Lanka, and Bangladesh. The results were analyzed using 14-year panel data from 2004 to 2017 with a two-step 
dynamic panel approach and discovered that product diversification and regional diversification significantly impacted the companies' financial success. The dividend policy and capital structure were also significantly affected the firm's financial performance.

The correlation between diversification and company performance changes among institutions was investigated by Mac-Ozigbo and Daniel (2020). They analyzed data from roughly 400 Nigerian private companies using two methods: panel and cross-period comparisons. Both approaches revealed that varied businesses outperformed specialised businesses. The higher the level of diversification, the better the firm's financial performance.

Cahyo, Kusuma, Harjito and Arifin (2021) studied the influence of firm diversification on firm performance moderated by firm life cycle stages of 127 Indonesian Stock Exchange-listed firms from 2011 to 2017 using the Generalized Method of Moment (GMM). The study main findings showed that the firm life cycle at the growth and maturity stage significantly strengthens the influence of firm diversification on firm performance. In contrast, the decline life cycle stage fails to moderate the relationship between diversification and firm performance.

From the various studies empirically reviewed on the relationship between corporate diversification and financial performance in different economies, industries, and time scope, previous studies either used the book/accounting (Return on Assets) measure of financial performance or the market value (Tobin's Q) of financial performance while using only one of the independent variable identified in this study (Product, conglomerate or geographical diversification). Since each measure of financial performance tends to have its drawbacks, this study intends to use both measures of financial performance identified in previous studies and determine the impact diversification will have on the two (2) identified performance measures.

\section{Research Methods}

This study employed a longitudinal research design involving repeated observations of the same variables (i.e., firms) over short or long periods. This study focused on corporate diversification strategy and financial performance of conglomerate firms listed on the Nigerian Stock Exchange from 2010 to 2019. Accordingly, the population of this study consists of all the Nine (9) conglomerates firms listed on the Nigerian Stock Exchange (NSE). This also constitutes the sample size for the study, making it a census sample. Relevant cross-sectional (Panel) data were sourced and computed from the annual reports of the sampled firms spanning 2010 to 2019.

Model Specification: To examine the effect of corporate diversification on the financial performance of conglomerate firms in Nigeria, two multiple linear models developed by Jasper (2016) were adopted for this study. The first model captures the contribution of product, geographical and conglomerate diversification on the financial performance of selected firms using Return of Assets (Book Value). The second model captures product, geographical, and conglomerate diversification's contribution to the financial performance of firms chosen using Tobin's Q (market value).

The functional form of the model is expressed below:

$R O A=F(P D I V, O D I V, G D I V, F S I Z E)$

TOBINS $Q=F(P D I V, O D I V, G D I V, F S I Z E)$

Where;

ROA $=$ Return on Assets

TOBINS Q $=$ Market Value of the Firm

PDIV = Product Diversification

ODIV = Operational/Conglomerate Diversification

GDIV $=$ Geographical Diversification

FSIZE $=$ Firm Size

Equations (i) and (ii) are expressed in mathematical form as follows:

$R O A_{i t}=a_{0}+a_{1} P D I V_{i t}+a_{2}$ ODIV $_{i t}+a_{3}$ GDIV $_{i t}+a_{4}$ FSIZE $_{i t}+\varepsilon_{i t} \quad--$

TOBINS $Q_{i t}=\beta_{0}+\beta_{1} P D I V_{i t}+\beta_{2}$ ODIV $_{i t}+\beta_{3}$ GDIV $_{i t}+\beta_{4}$ FSIZE $_{i t}+\varepsilon_{i t}-$

Where:

$\boldsymbol{i}=$ firm 1 to 9 for the nine (9) sampled firms.

$\boldsymbol{T}=$ the year 2010 to 2019 for nine (9) sampled firms.

$\boldsymbol{a}_{0}-\boldsymbol{a}_{4}, \boldsymbol{\beta}_{0}-\boldsymbol{\beta}_{4}$ are variables coefficients to be estimated.

$\varepsilon$ is the stochastic element representing other unspecified influence on return on asset and Tobin Q

The a priori expectations are: $\boldsymbol{\alpha}_{1}-\boldsymbol{\alpha}_{4}>0 ; \boldsymbol{\beta}_{1}-\boldsymbol{\beta}_{4}>0$

Panel Cointegration: Premise on the unit root test results, variables were subjected to a co-integration test to determine if a long-run relationship exists among them. As a panel study, the Pedroni panel co-integration test (1999) was employed to test for co-integration between variables of the study; following Pedroni's test, the Kao test for co-integration (1999) was also used in other to make the study robust. Model (iii) and (iv) is thus restated as: 


$$
\begin{gathered}
R O A_{i t}=a_{1}+a_{2} \sum_{\mathrm{t}-1}^{\mathrm{n}} \Delta R O A_{i t-1}+a_{3} \sum_{\mathrm{t}-1}^{\mathrm{n}} \Delta P D I V_{i t-1}+a_{4} \sum_{\mathrm{t}-1}^{\mathrm{n}} \Delta O D I V_{i t-1}+a_{5} \sum_{\mathrm{t}-1}^{\mathrm{n}} \Delta G D I V_{i t-1}+a_{6} \sum_{\mathrm{t}-1}^{\mathrm{n}} \Delta F S I Z E_{i t-1}+\varepsilon-(i v) \\
\text { TOBINS } Q_{i t}=\beta_{1}+\beta_{2} \sum_{\mathrm{t}-1}^{\mathrm{n}} \Delta T O B I N S Q_{i t-1}+\beta_{3} \sum_{\mathrm{t}-1}^{\mathrm{n}} \Delta P D I V_{i t-1}+\beta_{4} \sum_{\mathrm{t}-1}^{\mathrm{n}} \Delta O D I V_{i t-1}+\beta_{5} \sum_{\mathrm{t}-1}^{\mathrm{n}} \Delta G D I V_{i t-1}+\beta_{6} \sum_{\mathrm{t}-1}^{\mathrm{n}} \Delta F S I Z E_{i t-1}+\mathrm{\varepsilon}
\end{gathered}
$$

\begin{tabular}{|c|c|c|c|}
\hline & Variable & Mode Of Measurement & Source \\
\hline & \multicolumn{3}{|l|}{ Dependent Variables } \\
\hline 1 & Return on Assets (ROA) & $\frac{\text { Net profit after tax }}{\text { Total Assets }}$ & (Jasper, 2016) \\
\hline 2 & Tobin's Q & $\frac{\text { Total Market Value of Firm }+}{\frac{\text { Preference Shares }}{\text { Total Assets Value }}}$ & (Jasper, 2016) \\
\hline & \multicolumn{3}{|l|}{ Independent Variables } \\
\hline 1 & $\begin{array}{l}\text { Product Diversification } \\
\text { (PDIV): }\end{array}$ & $\frac{\text { Revenue From Product }}{\text { Total Revenue }}$ & $\begin{array}{l}\text { (Nasiru, Ibrahim, Yahya, \& } \\
\text { Aliyu, 2011; Akewushola, } \\
\text { 2015; Oyedijo 2012). }\end{array}$ \\
\hline 2 & $\begin{array}{l}\text { Operational } \\
\text { Diversification(ODIV) }\end{array}$ & $\frac{\text { Revenue From Conglomerate }}{\text { Total Revenue }}$ & $\begin{array}{l}\text { (Odunayo, Stephen, \& } \\
\text { Mabutho, 2017; Olu, 2009) }\end{array}$ \\
\hline 3 & $\begin{array}{l}\text { Geographical } \\
\text { Diversification (GDIV) }\end{array}$ & $\frac{\text { Revenue From Geographical location }}{\text { Total Revenue }}$ & $\begin{array}{l}\text { (Nejat, Rav, \& Fiona, 2015; } \\
\text { Talli \& Dovev, 2013; Aziz, } \\
\text { Ahmed, \& Murad, 2011; } \\
\text { Nigel, Jun, \& Sourafel, 2008; } \\
\text { Steven, Trahan, \& Gopala, } \\
\text { 2004; Hans, John, \& } \\
\text { Jacqueline, 2004) }\end{array}$ \\
\hline & Control Variables & & \\
\hline 1 & Firm Size (FSIZE) & Log of Total Assets & (Jasper, 2016) \\
\hline
\end{tabular}

Table 1. Measurements of Variables

Source: Authors compilation 2021

\begin{tabular}{|c|c|c|c|c|c|c|}
\hline & Tobins'Q & ROA & PDIV & ODIV & GDIV & Firm-size \\
\hline Tobin's Q & 1.00 & \multirow[b]{2}{*}{1.00} & & & & \\
\hline ROA & $\begin{array}{l}-0.624 \\
(0.002)\end{array}$ & & & & & \\
\hline PDIV & $\begin{array}{l}0.219 \\
(0.235)\end{array}$ & $\begin{array}{l}0.169 \\
(0.360)\end{array}$ & 1.00 & & & \\
\hline ODIV & $\begin{array}{l}0.293 \\
(0.108)\end{array}$ & $\begin{array}{l}-0.095 \\
(0.610)\end{array}$ & $\begin{array}{l}0.731 \\
(0.000)\end{array}$ & 1.00 & & \\
\hline GDIV & $\begin{array}{l}-0.736 \\
(0.000)\end{array}$ & $\begin{array}{l}0.220 \\
(0.234)\end{array}$ & $\begin{array}{l}0.274 \\
(0.135)\end{array}$ & $\begin{array}{l}-0.256 \\
(0.163)\end{array}$ & 1.00 & \\
\hline Firm_size & $\begin{array}{l}-0.692 \\
(0.000)\end{array}$ & $\begin{array}{l}0.187 \\
(0.312)\end{array}$ & $\begin{array}{l}0.108 \\
(0.56)\end{array}$ & $\begin{array}{l}-0.325 \\
(0.07)\end{array}$ & $\begin{array}{l}0.875 \\
(0.000)\end{array}$ & 1.00 \\
\hline
\end{tabular}

\section{Result and Discussion}

Source: Authors computation from E-views 9.0 output

The correlation matrix in Table II captures the co-movement between the study variables. The results show that only geographical diversification is found to be significantly correlated with Tobins'Q while the rest, although having a positive correlation, were insignificant. It is also found that diversification variables exhibit some form of correlation. For example, a robust correlation between operational and product diversification is found. This would mean that any conglomerate using one form of diversification would most likely engage in another form of diversification. Product and operational diversification are found to correlate with return on asset positively. This would imply that increase in the use of these forms of diversification would increase the return on assets of the firm

Table 3. Panel Unit Root Testing 


\begin{tabular}{|c|c|c|c|c|c|c|}
\hline \multirow[t]{2}{*}{ Variables } & \multicolumn{3}{|c|}{$\begin{array}{c}\text { Test assuming a standard unit root } \\
\text { process (LLC) }\end{array}$} & \multicolumn{3}{|c|}{$\begin{array}{c}\text { Test assuming individual unit root } \\
\text { process (IPS) }\end{array}$} \\
\hline & Levels & $1^{\text {st }}$ Diff & Remark & Levels & $1^{\text {st }}$ Dif & \\
\hline ROA & $\begin{array}{l}-4.381 \\
(0.000) * *\end{array}$ & $\begin{array}{l}-5.612 \\
(0.000)^{* *}\end{array}$ & $\mathbf{I}(\mathbf{0})$ & $\begin{array}{l}0.050 \\
(0.520)\end{array}$ & $\begin{array}{l}-2.958 \\
(0.000)^{* *}\end{array}$ & $\mathbf{I}(\mathbf{1})$ \\
\hline TQ & $\begin{array}{l}-32.223 \\
(0.000)^{* *}\end{array}$ & $\begin{array}{l}-35.356 \\
(0.000)^{* *}\end{array}$ & $\mathbf{I}(\mathbf{0})$ & $\begin{array}{l}-18.718 \\
(0.000)^{* *}\end{array}$ & $\begin{array}{l}-19.516 \\
(0.000)^{* *}\end{array}$ & $\mathbf{I}(\mathbf{0})$ \\
\hline PDIV & $\begin{array}{l}-1.223 \\
(0.110)\end{array}$ & $\begin{array}{l}-4.564 \\
(0.000)^{* *}\end{array}$ & $\mathbf{I}(\mathbf{1})$ & $\begin{array}{l}0.506 \\
(0.693)\end{array}$ & $\begin{array}{l}-1.596 \\
(0.05)^{*}\end{array}$ & I(1) \\
\hline GDIV & $\begin{array}{l}0.430 \\
(0.427) \\
\end{array}$ & $\begin{array}{l}-2.252 \\
(0.012)^{*}\end{array}$ & I(1) & $\begin{array}{l}-1.182 \\
(0.103) \\
\end{array}$ & $\begin{array}{l}-3.579 \\
(0.028)^{*}\end{array}$ & $\mathbf{I}(\mathbf{1})$ \\
\hline ODIV & $\begin{array}{l}-1.166 \\
(0.121) \\
\end{array}$ & $\begin{array}{l}-2.534 \\
(0.005)^{* *}\end{array}$ & $\mathbf{I}(\mathbf{1})$ & $\begin{array}{l}1.682 \\
(0.752) \\
\end{array}$ & $\begin{array}{l}-3.454 \\
(0.041)^{*}\end{array}$ & $\mathbf{I}(\mathbf{1})$ \\
\hline Fs & $\begin{array}{l}-2.144 \\
(0.016)^{*}\end{array}$ & $\begin{array}{l}-4.873 \\
(0.009) * *\end{array}$ & $\mathbf{I}(\mathbf{0})$ & $\begin{array}{l}-1.705 \\
(0.240)\end{array}$ & $\begin{array}{l}-5.338 \\
(0.009)^{* *}\end{array}$ & $\mathbf{I}(\mathbf{1})$ \\
\hline
\end{tabular}

Source: Authors computation from Eviews 9.0 output. * and ** indicate significance at the $1 \%$ and $5 \%$ level, respectively

Table 3 depicts the stationarity of variables giving different assumptions. Result suggests that some of the series are stationary at levels giving different assumptions of homogeneity and heterogeneity of unit root process. Performance indicators are stationary at levels, and results show that Firm Size is only stationary at levels, giving the common unit root process assumptions. In all, all series are found to be stationary after being subjected to their first difference and therefore most of the series are can be categorized as an I(1) variable although some showed elements of being an I(0) variable. We continue to establish their long term connection since the variables are likewise stationary after initial difference.

Table 4. Co-Integration Test

\begin{tabular}{|c|c|c|c|c|c|}
\hline \multicolumn{5}{|c|}{ Pedroni Residual Cointegration Test } & \multirow[t]{2}{*}{$\begin{array}{c}\text { Kao Residual } \\
\text { Test } \\
\end{array}$} \\
\hline & Statistic & Weighted Statistics & & Statistics & \\
\hline \multicolumn{6}{|c|}{ TQ equation } \\
\hline Panel v & $4.511069 *$ & $4.511069 *$ & Group rho & $4.428074 *$ & \multirow[t]{4}{*}{$-3.552559 *$} \\
\hline Panel rho & $6.019512 *$ & $6.019512 *$ & Group PP & $-6.644036^{*}$ & \\
\hline Panel PP & $-5.662408 *$ & $-5.662408 *$ & Group ADF & $5.838983 * *$ & \\
\hline Panel ADF & $-4.436570 *$ & $-4.436570 *$ & & & \\
\hline \multicolumn{6}{|c|}{ ROA Equation } \\
\hline Panel v & $4.718264 *$ & 4.718264 & Group rho & 0.915491 & \multirow[t]{4}{*}{$-7.491007 *$} \\
\hline Panel rho & $6.461925^{*}$ & $6.461925^{* *}$ & Group PP & $4.303584 *$ & \\
\hline Panel PP & 0.000197 & 0.000197 & Group ADF & $3.684907 *$ & \\
\hline Panel ADF & $4.126035^{*}$ & 4.126035 & & & \\
\hline
\end{tabular}

Source: Authors computation from Eviews 9.0 Output. * and ** indicate significance at the $1 \%$ and $5 \%$ level of significance

Pedroni's and Kao's panel cointegration tests on the series between the dependent variable and the explanatory factors for the two models selected for the study are shown in Table IV. The data shows that both grouped and ungrouped tests findings were significant at the $1 \%$ and $5 \%$ levels. This null hypothesis, which states that there is no co-integration between the independent and dependent variables, is thus rejected for the combination of the variables. This illustrates the persistence of a relationship over a lengthy period of time.

Table 5. Huasman's Test Result

\begin{tabular}{lccc}
\hline \multicolumn{1}{c}{ Equation } & Chi-Sq. Statistics & Chi-Sq d.f. & Prob \\
\hline TQ & 7.828135 & 4 & 0.0981 \\
\hline ROA & 5.652315 & 4 & 0.2267 \\
\hline
\end{tabular}

Source: Authors Computation from Eviews 9.0 Output

The result from Table 5 above shows the test result of both equations. When Tobins'Q (TQ) is the dependent variable, result shows that there was enough empirical proof to reject the null hypothesis of using the Random effect model. Therefore, for the Tobins'Q equation the fixed effect model would be used for analysis. For the ROA equation, statistical result was not strong enough to reject the null hypothesis and therefore the use of random effect model to capture the relationship between the variables in the model are dependent and independent. 
Table 6. Regression Summary (ROA equation) with Random Effect

\begin{tabular}{clll}
\hline Variable & $\begin{array}{c}\text { Beta } \\
\text { Coeffcient }\end{array}$ & t-statistic & P.value \\
\hline PDIV & 0.268892 & 4.075665 & $0.0063^{* *}$ \\
\hline ODIV & -0.740833 & -3.613713 & $0.0309^{*}$ \\
\hline GDIV & -0.577881 & -3.858121 & $0.0027^{* *}$ \\
\hline FIRM_SIZE & 0.155486 & 3.009387 & $0.0256^{*}$ \\
\hline C & -35.85493 & -0.269254 & 0.7899 \\
\hline R-square & 0.528 & & \\
\hline Ajusted.R.square & 0.505 & & \\
\hline D-Watson & 2.508219 & & \\
\hline Prob(ftat & 14.04141 & & \\
\hline
\end{tabular}

Source: Authors computation from Eviews 9.0 output. * and ** indicate significance at the 1 percent and 5\% level of significance

Table 6 shows the impact of corporate diversification on firm performance when ROA is the dependent variable. Diagnostic test from the first model reveals that the models explanatory power is fair. Result shows that 52 percent of variations of ROA are explained by the explanatory variable. Therefore, we can say that the models explanatory power is fair. Interesting transmission patterns is found flowing from corporate diversification to firm's performance. Only PDIV is found to have a positive relationship with performance when ROA is the dependent variable, while other diversification variables are found to record an inverse relationship with performance. Speaking in specific terms, PDIV is found to positively reinforce ROA and this relationship is found to be statistically significant. Its large positive coefficient indicates the robustness of the estimated model. This coefficient is significant at the 1 percent level. This implies that product diversification exhibits substantial positive impacts on ROA among the conglomerates, irrespective of the controlled factors in the model.

On the other hand, operational and geographical diversification inhibit the ROA of conglomerate firms. This reflects instability in the estimated equations and shows that variation in these two forms of diversification would likely lead to further disequilibrium in the equation. This negative relationship between Operational and geographical diversification with ROA is statistically significant at the 5\% level. Firm size reinforces ROA in the equation positively, indicating that larger firms tend to have a more extensive stock of assets hence more significant returns.

Table 7. Regression Summary (Tobin's Q equation) with Fixed Effect

\begin{tabular}{clll}
\hline Variable & $\begin{array}{c}\text { Beta } \\
\text { Coeffcient }\end{array}$ & t-statistic & P.value \\
\hline PDIV & 0.189525 & 0.944242 & 0.3549 \\
\hline ODIV & -0.079420 & -1.857764 & 0.0761 \\
\hline GDIV & -0.027729 & -0.192988 & 0.8487 \\
\hline FIRM_SIZE & -16.38841 & -5.079348 & 0.0000 \\
\hline \multicolumn{1}{c}{ C } & 124.8197 & 5.522539 & 0.0000 \\
\hline R-square & 0.902598 & & \\
\hline D-Watsted.R.square & 0.872953 & & \\
\hline F.stat & 2.117593 & & \\
\hline Prob(f-stat) & 30.44768 & & \\
\hline Sours: Auths & 0.000000 & & \\
\hline
\end{tabular}

Source: Authors computation from Eviews 9.0 output. * and ** indicate significance at the 1 percent and 5 percent significance levels.

Table 7 captures the relationship between corporate diversification and the firm's performance when Tobin's $\mathrm{Q}$ is the dependent variable. The diagnostic test indicates that the specified model explains about $90 \%$ variations in the dependent variable; therefore, one can conclude that the model's explanatory power is high. Again the adjusted R-square indicates that the model still poses a high explanatory power even after a degree of freedom has been considered. From the results in Table VII, corporate diversification is found to exhibit different relationships with performance depending on diversification. For example, while product diversification reinforces the firm's value, operational and geographical diversifications inhibit it.

Product diversification, in particular, is found to reinforce a firm's value, and this relationship is found to be statistically insignificant at the 5\% level. This implies that their market value would be strengthened as firms dive into new products. Therefore, this result reveals that with increased diversification of the firm's products, conglomerates tend to gain an edge over competitors in increasing market value. On the contrary, it 
is found that Geographical diversification inhibits a firm's value as measured by Tobin's Q. This demonstrates that geographical diversity also tends to diminish Tobin's Q, which contradicts apriori assumptions since more global diversification should increase the value of conglomerates through asset base growth. However, this result reveals that geographical diversification would tend to depreciate firms' market value for conglomerates understudy.

Similarly, operational diversification is found to inhibit a firm's market value, and this relationship is insignificant. This does not follow apriori as firms' value is expected to improve given improved operations changes leading to greater efficiency. The small coefficient of operational diversification indicates that although a negative and insignificant relationship exists, such a relationship is not robust enough, and transmission patterns may be slow. Finally, firm size is negatively and significantly related to the market value. Signifying that large firms necessarily do not increase market value, larger firms experience a drop in their market value. This result implies that an increase in the market value of large firms is not due to its size, as size is seen to inhibit market value and not reinforce it.

\section{Findings}

Results from the empirical analysis are far-reaching and have vital policy implications. First, the sampled conglomerates all have some variants of our selected explanatory variables and control variables within the scope of our study. Using the panel least square methodology, product diversification empirically and significantly impacted the performance of conglomerates in Nigeria. A positive and significant impact was recorded in the market base measure of performance (TobinQ), while a negative relationship was recorded in the accounting-based measures of performance (ROA). This indicates that an increase in product diversification will also lead to a positive and significant increase in the firm's market value and inhibit return on assets. This finding implies that conglomerates in Nigeria can improve their market performance from other income-earning derived from diversification of their products through value creation and risk reduction. These findings corroborate the findings of Talat, Choudhary, and Mian (2008), as well as Oyedijo (2012), who demonstrated a favorable and substantial effect of product diversity on firm performance in their respective research.

Secondly, the study empirically established that operational diversification and performance of conglomerates was positive and significant regarding Tobin's $\mathrm{Q}$, which is in line with the submission of Ugwuanyi and Ugwu (2012). Again, when Return on Asset (ROA) was used as the performance metric, operational diversification showed a substantial negative connection with the aforementioned dependent variables. This discovery corroborates the findings of Odunayo, Stephen, and Mabutho (2017). The upshot of these contradictory findings is that when conglomerates diversify their operations, they lose a competitive advantage in increasing their respective market values. Again, as it relates to geographical diversification, the empirical result revealed a negative and significant effect on the performance of conglomerates under study. This finding is in accord with Nejat, Rav, and Fiona's (2015) study, which submitted that geographical diversification has a negative and significant relationship with the firm's performance. This empirical finding implies that quoted conglomerates' market and firm value will be inhibited when they venture into other geographic terrains.

\section{Conclusion}

We have painstakingly considered corporate diversification related to the performance of conglomerates in Nigeria. From the several findings derived from the study, we conclude that corporate diversification has a dominant-negative impact on financial performance. However, only one form of corporate diversification (product) was positively related to financial performance. Against this milieu, this study concludes that corporate diversification has a negative impact on firms' performance as most forms of corporate diversification measures were found to inhibit performance.

\section{Recommendations}

The results from the empirical analysis provide strong background and implications to allow for a particular policy and practical recommendations for practitioners and policymakers. Geographical diversification as a strategy for corporate development and growth tends to influence the financial performance of conglomerates firms in Nigeria significantly. Conglomerates should therefore focus more on using this strategy than other types of diversification strategy as discussed in this study. This type of diversification encompasses a great deal of product and services promotions which is key to improving annual sales and product awareness. The government should use its fiscal policy influence to solve the country's severe infrastructure deficit (roads, telecoms, railways, power, and so on). Similar initiatives are needed to improve the country's numerous institutions. The combined effect of these initiatives will result in a significant reduction in the cost of doing business in Nigeria.

\section{References}

Athar. I., Irfan. H., \& Majid. Q. (2012). Impact of diversification on firms' performance. American Journal of Scientific, Issue 80, 42-53. 
Archana, R., \& Saumitra, B. (2015). Diversification and firm performance: a study of Indian manufacturing firms. Madras School of Economics, MPRA Paper No. 68013, 1-27.

Akewushola, R., O. (2015). performance effectiveness of related product market diversification strategy in Nigerian companies: information and communication technology as a virile tool. Journal of Policy and Development Studies. 9(2), 211-219.

Aziz, B., Ahmed, E., \& Murad, M. (2011). Resource allocation, level of international diversification, and firm performance. International Journal of Business and Management, 6(12), 87-93.

Cahyo, H., Kusuma, H., Harjito, D. A. \& Arifin, Z. (2021). The relationship between firm

diversification and firm performance: Empirical evidence from Indonesia. Journal of Asian Finance, Economics, and Business. 8(3), 497-504.

Clarke, R. (1985). Industrial Economics, London, Basil Blackwell Ltd.

Chia-Wen, H., \& Heng-Yih, L. (2008). Corporate diversification and firm performance: the moderating. Role of the contractual manufacturing model. Asia Pacific Management Review, 13(1), 345-360.

Hans, V., K., John., H., \& Jacqueline, P. (2004). Measurement of international and product diversification in the publishing industry. The Journal of Media Economics, 17(2), 87-104.

Imen, K., \& Mehdi, S., S., (2011). Corporate diversification and earnings management. Review of Accounting And Finance, 10 (2), 176-196.

Jasper., V., D., B. (2016). The effect of the global financial crisis on diversification in India is corporate diversification and firm performance. Master Thesis. University Of Groningen: 2033410.

John, A., D., \& Lang (2003). Foreign direct investment, diversification, and firm performance. Journal of International Business Studies. 34, 153-172.

Kotler. P., \& Armstrong, G. (2008). Marketing: An Introduction. New Jersey. Prentice-Hall International, Inc.

Kuria, T., W. (2016). The effects of corporate diversification on the financial performance of non-financial firms listed at the Nairobi Securities Exchange. A Research Project Submitted In Partial Fulfilment Of The Requirements For The Award Of The Degree Of Master Of Science In Finance, School Of Business, The University Of Nairobi October 2016.

Mac-Ozigbo, A., \& Daniel, C. O. (2020). Diversification Strategy and Financial Performance of Nigeria Private Firms.

Mehmood, R., Hunjra, A. I., \& Chani, M. I. (2019). The impact of corporate diversification and financial structure on firm performance: evidence from South Asian countries. Journal of Risk and Financial Management, 12(1), 49.

Meysam, D., Melati, A., A., \& Zuhaimy, I. (2015). Corporate diversification and efficiency of manufacturing firms listed in bursa Malaysia. Iranian Journal Of Management Studies (IJMS) Http://Ijms.Ut.Ac.Ir/ 8( 4).

Murali, D.,R., Chari, A., Sarv, D., \& Parthiban, D. (2007). International diversification and firm performance: role of information technology investments. Journal of World Business 42 (27) 184-19.

Nasiru, A., Ibrahim, K., Z., Yahya, M., I., \& Aliyu, M., I. (2011). Evaluating the impact of product diversification on the financial performance of selected Nigerian construction firms. Journal of Construction in Developing Countries, 16(2), 91-114.

Nejat, C., Rav, C., \& Fiona, S. (2015). Effects of international diversification and firm resources on firm performance risk. Journal of Management and Strategy, 6(1), 72-85

Nigel, D., Jun, D., \& Sourafel, G., (2008). Optimal geographic diversification and firm performance. Springer Science Business Media, Llc, 145-154.

Odunayo. M., O., Stephen, O., M., \& Mabutho, S. (2017). Functional diversification and financial performance of sub-Saharan Africa commercial banks: static and dynamic approach. Financial Institutions And Services. ACTA Universitatis Danubius (13)5, 17-28

Ongeri, B., N. (2014). The relationship between corporate diversification and capital structure of firms listed at the Nairobi securities exchange. A Research Project Submitted In Partial Fulfilment Of The Requirements For Award Of Degree Of Master Of Business Administration, School Of Business, University Of Nairobi.

Olu, O. (2009). Corporate diversification and firm performance: an empirical study. Current Economic Crisis. 9, 39-50.

Oweis, A. (2012). The impact of corporate diversification on the financial performance of U.S. bank holding companies pre and post the financial services modernization act of 1999.

Oyedijo, A. (2012). Effects of product-market diversification strategy on corporate financial performance and growth: an empirical study of some companies in Nigeria. Global Advanced Research Journal of Management and Business Studies, 1, 61-69.

Pandya, A., M. \& Rao, N., V. (1998). Diversification and firm performance: an empirical evaluation. Journal of Financial and Strategic Decisions, 11(2), 67-81.

Pisedtasalasai, A. \& Edirisuriya, P. (2020). Diversification and performance of Sri Lankan banks. Journal of Asian Finance, Economics, and Business, 7(9), 1-10. 
Ranka, K., Vladimir, N., \& Dragan, S. (2017). Effects of corporate diversification on firm performance: evidence from the Serbian insurance industry, Economic Research-Ekonomska Istraživanja, 30 (1), 1224 1236.

Salma, U., \& Hussain, A., (2018). A comparative study on corporate diversification and firm performance across South Asian countries. Journal of Accounting \& Marketing, 7(1), 421-428.

Steven, F., E., Trahan, A., \& Gopala, K., V. (2004). Effects of global and industrial diversification on firm value and operating performance. Financial Management Association Meetings And The Spring, Finance Seminar Series At Hofstra University.

Sumra, L., M., \& Muhammad, A., S. (2014). Detailed analysis on the relationship between group's diversification into the financial services industry and its impact on their financial performance. Research Journal of Finance and Accounting, 5(5), 126-145

Talat, A., Choudhary, S., \& Mian, S., N. (2008). Diversification and corporate performance: an evaluation of Pakistani firms. South Asian Journal of Management, 15(3), 8-18.

Talli, Z., \& Dovev, L. (2013). Intra-industry diversification and firm performance. Strategic Management Journal, 34, 978-998.

Ugwuanyi, G., O., \& Ugwu, J., O. (2012). The effect of corporate diversification on the profitability of the financial services sector in Nigeria. World Academy of Science, Engineering and Technology International, Journal of Economics and Management Engineering, 6(7), 1729-1733. 